\title{
PENGEMBANGAN APLIKASI MOBILE UNTUK PENYEDIAAN INFORMASI SEKITAR KAMPUS BINUS BERBASIS WEB
}

\author{
Agustinna Yosanny; Adriani Halim \\ Computer Science Department, School of Computer Science, Binus University \\ Jl. K.H. Syahdan No. 9, Palmerah, Jakarta Barat 11480 \\ ayosanny@binus.edu; izark@binus.edu
}

\begin{abstract}
Sometimes we find difficulties in obtaining the necessary information as limited to place and time, as well as the media used. One example is limitations in obtaining the necessary information about facilities available at the nearby of Binus University campus. Based on this case, we propose information media providing facilities around Binus University campus that can be accessed anytime and anywhere using mobile web technology guided by Google maps. The features of Google maps can also help users locate the facility. The methodology used in this research is analysis and design. Results that can be obtained from this research is a mobile-web application that provides complete information about the environment around BINUS campus that can be accessed by students and the surrounding community. Using this application, BINUS students can obtain the necessary information about the campus environment easily and quickly.
\end{abstract}

Keywords: information, mobile, internet, campus facilities, environment, Goggle maps

\begin{abstract}
ABSTRAK
Kebutuhan akan informasi sangatlah penting di dalam kehidupan. Tapi kadangkala terdapat kesulitan dalam memperoleh informasi yang diperlukan karena terbatas pada tempat dan waktu, serta media yang digunakan. Salah satu contoh kasus adalah keterbatasan sumber dalam memperoleh informasi yang diperlukan tentang fasilitas yang terdapat di sekitar kampus Binus University. Beranjak dari kebutuhan informasi dan keterbatasan di atas, penelitian ini bertujuan untuk membuat suatu media informasi tentang fasilitas-fasilitas dan lokasi yang berada di sekitar kampus BINUS University yang dapat diakses kapan dan di mana saja dengan memanfaatkan teknologi mobile web yang dipandukan dengan google maps. Fitur dari google maps ini juga dapat membantu pengguna mencari lokasi fasilitas. Metodologi yang digunakan dalam penelitian ini adalah metode analisis dan perancangan. Hasil yang dapat diakses dari penelitian ini adalah sebuah aplikasi yang dapat menampilkan kelengkapan informasi tentang lingkungan sekitar kampus BINUS yang dapat diakses oleh mahasiswa BINUS (khusus) dan masyarakat sekitar (umum). Aplikasi dikemas dalam bentuk mobile web yang dapat diakses di mana dan kapan saja menggunakan koneksi internet. Dengan aplikasi ini, diharapkan mahasiswa BINUS dapat memperoleh informasi yang diperlukan dengan mudah dan cepat tentang lingkungan sekitar kampus BINUS.
\end{abstract}

Kata kunci: informasi, mobile, internet, fasilitas kampus, lingkungan sekitar, Goggle Maps 


\section{PENDAHULUAN}

Perkembangan teknologi informasi yang semakin pesat, telah berpengaruh terhadap kecepatan dalam mendapatkan informasi. Misalnya, sekitar dua puluh tahun yang lalu untuk mendapatkan informasi mengenai alamat dari suatu toko, perlu membuka buku yellow pages kemudian mencari detil toko tersebut pada halaman yang tertera. Tetapi saat ini, untuk mendapatkan informasi yang sama, hanya perlu mengetikkan nama toko tersebut di situs penelusuran seperti Google. Ditambah lagi dengan adanya situs penyedia peta virtual seperti google maps, yang semakin memudahkan untuk mencari lokasi toko tersebut. Perkembangan teknologi informasi juga mendorong berkembangnya perangkat mobile seperti ponsel pintar dan PC tablet yang memungkinkan pengguna untuk mengakses internet dan situs-situs seperti layaknya personal computer. Seorang analisis internet yang bernama Meeker (dikutip oleh Ingram, 2010) memprediksikan bahwa pengguna mobile internet akan melampaui pengguna personal komputer dalam lima tahun mendatang. Perubahan ini telah terlihat di Indonesia di mana 61\% pengguna internet di Indonesia menggunakan perangkat mobile untuk mengaksesnya (The Jakarta Post, 2011).

Aplikasi mobile web (Fling, 2009) merupakan suatu aplikasi yang dibangun menggunakan XHTML, CSS, dan Javascript di mana dapat diakses oleh pengguna melalui penjelajah situs mobile. Aplikasi mobile web ini tidak perlu di-install ataupun dikompilasi pada perangkat mobile dan memungkinkan pengguna untuk berinteraksi dengan konten dalam kondisi yang real-time, di mana aksi untuk menjelajah aplikasi ini biasanya dilakukan dengan cara klik atau touch.

Berbeda dengan pengguna internet pada komputer desktop, pengguna mobile web mempunyai karakteristik yang lebih sering bergerak dan ada kemungkinan untuk melakukan kegiatan lain ketika mengakses internet. Oleh karena itu prinsip desain untuk pengembangan mobile web juga mengalami perbedaan dari prinsip desain situs biasa. Frederick dan Lal (2009) menjabarkan prinsip-prinsip untuk mengakomodasi pengguna mobile web antara lain: (1) penyederhanaan fitur dan pelayanan, contohnya menggunakan singkatan atau kata-kata yang pendek untuk navigasi; (2) satu halaman untuk satu topik; (3) konsisten dengan tema situs; (4) penggunaan warna, pertimbangkan pengaruh cahaya matahari atau bayangan ketika pengguna di luar atau di dalam ruangan; (5) keindahan visual; (6) merancang navigasi situs yang langsung dimengerti. Kalau memerlukan halaman bantuan, sebaiknya cukup satu halaman saja; (7) minimalisasi pengetikan atau input teks. Jika memungkinkan, lebih baik memberikan pilihan kepada pengguna.

Dalam beberapa tahun terakhir telah banyak aplikasi mobile yang dikembangkan untuk keperluan universitas. Harvard University meluncurkan situs Harvard Mobile, University of California mengembangkan UCLA Mobile, dan Massachusetts Institute of Technology mengembangkan MIT mobile. Ketiga aplikasi mobile ini bertujuan untuk menyampaikan informasi yang dapat diakses melalui mobile phone oleh komunitas mereka dan juga seluruh dunia.

Kecenderungan penggunaan perangkat mobile untuk mencari informasi mungkin merupakan salah satu faktor yang telah mendorong Binus University untuk turut serta dalam mengembangkan aplikasi versi mobile web dari situs perpustakaannya (http://m.library.binus.ac.id). Namun akses perpustakaan secara mobile ini mungkin masih belum mencukupi kebutuhan informasi yang dibutuhkan oleh mahasiswa Binus University. Seiring berkembangnya infrastruktur BINUS University ini juga memberikan dampak pada perkembangan lingkungan sekitar kampus untuk memenuhi kebutuhan mahasiswa Binus University. Dengan perkembangan lingkungan kampus ini, kebutuhan mahasiswa Binus University akan informasi mengenai lingkungan kampusnya juga meningkat.

Dari hasil studi pendahuluan juga didapati bahwa sumber informasi mengenai fasilitas di sekitar Binus University saat ini biasanya diakses dari para mahasiswa senior dan forum diskusi. Hal 
ini menunjukkan bahwa terdapat keterbatasan sumber dalam memperoleh informasi yang diperlukan tentang fasilitas yang terdapat di sekitar kampus. Apalagi kalau fasilitas tersebut terdapat di lokasi yang berada pada jalan atau gang kecil, akan lebih menyulitkan dalam mencarinya. Ditambah dengan banyaknya bangunan-bangunan di sekitar kampus yang tidak mempunyai atau menempelkan nomor bangunan tersebut sehingga sulit teridentifikasi.

Telah banyak penelitian yang dilakukan berhubungan dengan pengembangan aplikasi mobile untuk berbagai macam kebutuhan universitas dengan hasil yang bervariasi. Sebagai contoh, Chen (2009) meneliti penggunaan sistem informasi mobile untuk sistem keamanan kampus dan Ashraf dan Kamal (2010) meneliti penerapan mobile marketing untuk mahasiswa. Di antara sekian banyak penelitian ini, ada beberapa penelitian yang lebih menekankan penyediaan informasi untuk mahasiswa.

Wilson dan McCarthy (2010) mengembangkan aplikasi mobile yang memberikan jalan lain untuk mengakses fasilitas-fasilitas Ryerson University dan juga berfungsi sebagai media informasi. Hasil penelitian mereka menunjukkan bahwa fitur yang paling banyak digunakan adalah fitur jadwal mahasiswa.

Asif dan Krogstie (2011) meneliti penerimaan mahasiswa akan sistem informasi berbasis mobile. Hasil penelitian mereka menunjukkan bahwa sistem informasi tersebut diterima baik oleh para mahasiswa dan sistem ini lebih bermanfaat bagi mahasiswa baru dibandingkan mahasiswa senior. Fitur pencarian lokasi merupakan fitur yang paling berguna bagi para mahasiswa.

Beranjak dari kebutuhan informasi dan keterbatasan di atas, penelitian ini bermaksud untuk membuat suatu media informasi tentang fasilitas-fasilitas dan lokasi yang berada di sekitar kampus Binus University di mana media ini dapat diakses kapan dan di mana saja dengan memanfaatkan teknologi mobile web yang dipandukan dengan google maps. Dengan adanya fitur dari google maps ini juga dapat membantu pengguna dalam mencari lokasi fasilitas yang diinginkan.

\section{METODE}

Metodologi penelitian berikut memperlihatkan tahapan-tahapan yang dilaksanakan di dalam penelitian, sehingga penelitian ini dapat dilakukan dengan terarah, jelas, dan efisien. Di mana tahapan yang dilakukan meliputi 6 tahapan, yaitu: studi pendahuluan, pengumpulan data, analisis penelitian, perancangan aplikasi, pengembangan aplikasi, dan evaluasi penelitian. Pada penelitian pendahuluan ini dilakukan dengan mencari jurnal-jurnal yang sesuai dengan topik penelitian yang ada untuk mengetahui penelitian-penelitian sebelumnya tentang topik serupa sehingga dapat dikembangkan. Selain itu juga dilakukan observasi untuk mengetahui informasi-informasi yang biasa diperlukan oleh mahasiswa dan karyawan Binus University tentang lokasi dan fasilitas yang berada di sekitar kampus.

Pada tahap pengumpulan data ini dilakukan melalui survei dan studi pustaka. Survei yang dilakukan dengan cara membagikan kuisioner dan wawancara. Hal ini dilakukan untuk mengetahui kebutuhan pengguna terhadap aplikasi yang akan dirancang. Beberapa data yang dikumpulkan antara lain: (1) perangkat mobile yang umum dipakai pada saat ini; (2) karakteristik pengguna perangkat mobile yang sesuai untuk perkembangan aplikasi ini; (3) informasi mengenai lokasi sekitar BINUS University. Selain itu juga dilakukan studi pustaka melalui buku-buku, referensi, jurnal ilmiah, serta pendukung lainnya. Studi pustaka ini dilakukan untuk mengetahui langkah-langkah yang sebaiknya dilakukan, metode yang cocok untuk diterapkan dalam proses pengembangan, serta teknologi yang digunakan. Hasil dari studi pendahuluan dan pengumpulan data akan di analisis untuk mengetahui kebutuhan pengguna akan aplikasi yang akan dirancang. Sehingga diharapkan hasil penelitian ini 
dapat diimplementasikan bukan hanya pada satu macam kebutuhan informasi saja dan juga dapat disajikan sebagai sarana bisnis dengan menjualnya kepada instansi lain yang memerlukan media informasi yang dapat diakses kapan dan di mana saja dengan menggunakan koneksi internet.

Tahap perancangan yang dilakukan berasal dari hasil analisis. Perancangan tersebut meliputi perancangan user interface, perancangan sistem dan perancangan basis data. Pada tahap pengembangan aplikasi dilakukan sesuai dengan hasil perancangan, yaitu aplikasi mobile web yang dapat dibuka dengan menggunakan web browser dan pada perangkat mobile phone. Pengembangan aplikasi ini dilakukan dengan menggunakan xhtml, css, java script, serta php dan mysql dan menerapkan teknologi responsive web. Evaluasi dilakukan untuk mengetahui apakah hasil dari penelitian ini sudah sesuai dengan kebutuhan pengguna. Sebelum melakukan evaluasi maka dilakukan terlebih dahulu implementasi terhadap hasil pengembangan aplikasi kepada pengguna sehingga pengguna tersebut dapat memberikan feedback yang akan diperbaiki selanjutnya.

\section{HASIL DAN PEMBAHASAN}

Mahasiswa Binus University memperoleh suatu informasi mengenai lokasi tertentu biasanya melalui forum atau mahasiswa senior. Hal ini kurang efisien karena mahasiswa perlu mengenal mahasiswa senior terlebih dahulu atau mengakses forum. Oleh karena itu, diusulkanlah sebuah aplikasi yang menyediakan informasi-informasi tentang fasilitas dan lokasi yang berada di sekitar kampus Binus University yang dapat diakses kapan dan di mana saja. Aplikasi ini dituangkan ke dalam mobile web dengan memadukan google maps.

\section{Perancangan Aplikasi}

Aplikasi ini dirancang berbasis web dan dijalankan pada perangkat mobile phone. Aplikasi ini mempunyai beberapa fungsi yang dapat dilihat dari Gambar 1 dan 2 di bawah ini.

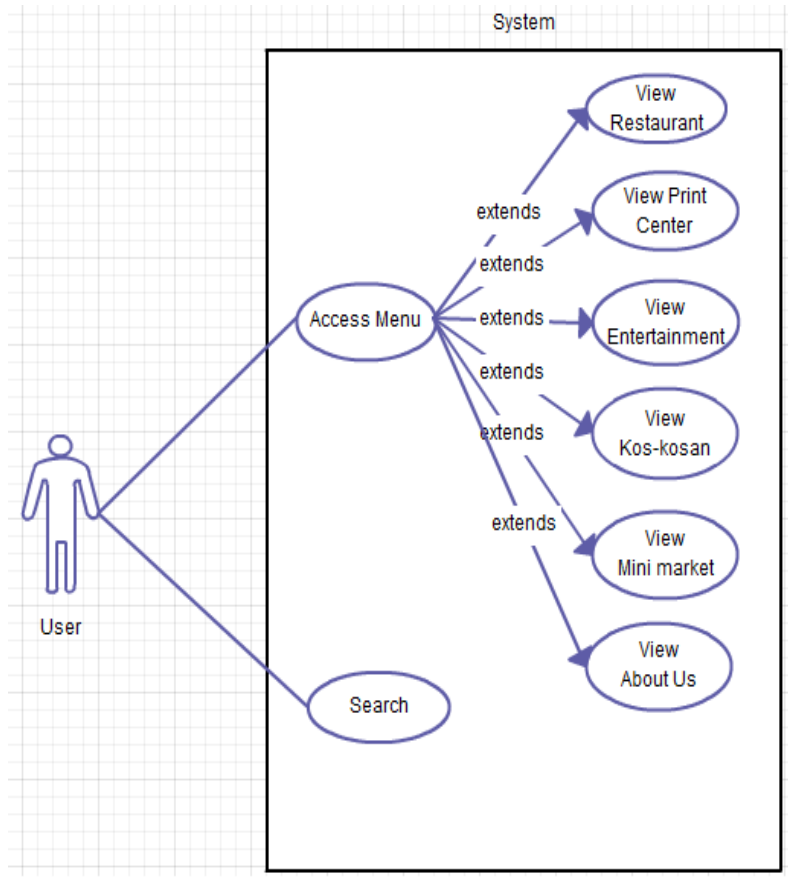

Gambar 1 Use case diagram pengguna 


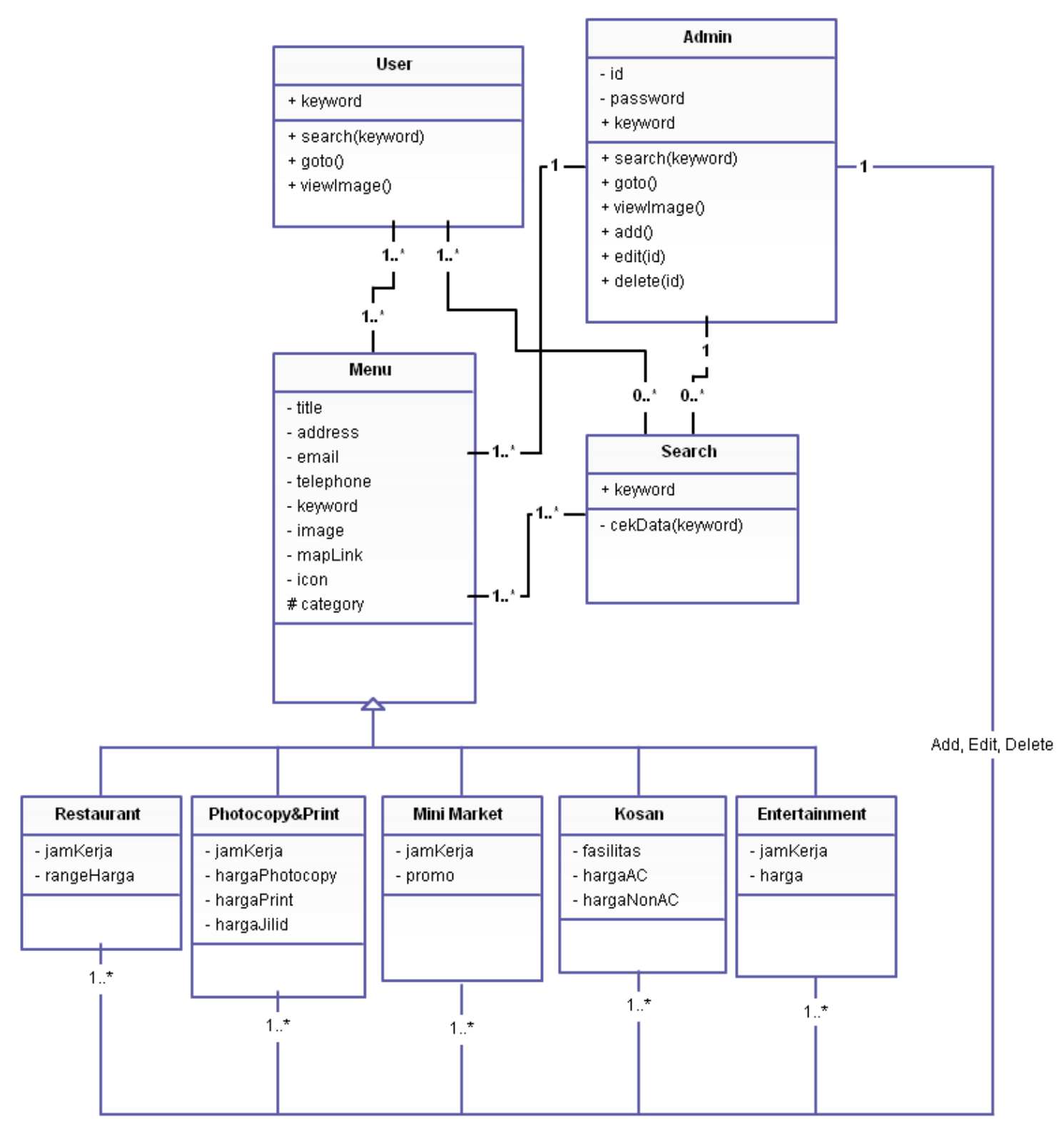

Gambar 2 Class diagram

Dari hasil perancangan system, dilakukan pengembangan terhadap aplikasi menggunakan bahasa pemrograman xHTML, CSS, java script dan php serta mysql untuk penyimpanan databasenya.

Aplikasi ini terdiri dari dua, yaitu aplikasi untuk admin yang digunakan untuk mengatur konten dari aplikasi dan aplikasi untuk pengguna. Untuk membuka aplikasi mobile web ini, pengguna dapat mengetikkan url beelife.net46.net pada browser di mobile pengguna. Setelah itu akan tampil halaman utama dari web tersebut.

Halaman home (Gambar 3) merupakan halaman utama atau awal yang dapat dilihat oleh pengguna setelah membuka web ini. Pada halaman ini, terdapat enam menu yaitu restaurant, print center, entertainment, boarding, mini market, dan about us. Pengguna dapat memilih salah satu menu tersebut, untuk menuju ke halaman sub menu dan halaman about us. Pengguna juga dapat mengontrol 
ukuran huruf pada halaman ini dengan men-tap menu small atau normal. Pada halaman sub menu (Gambar 4) terdapat sub menu yang dapat dipilih oleh pengguna untuk melihat detail informasi dari sub menu yang dipilih. Link back to top dapat di-tap oleh pengguna, untuk menuju ke bagian atas halaman ini. Menu back to home dapat di-tap oleh pengguna untuk menuju ke halaman home.

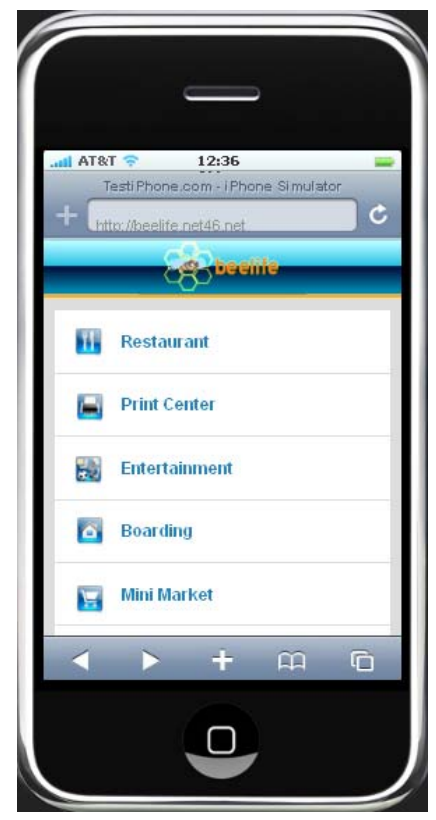

Gambar 3 Tampilan halaman home

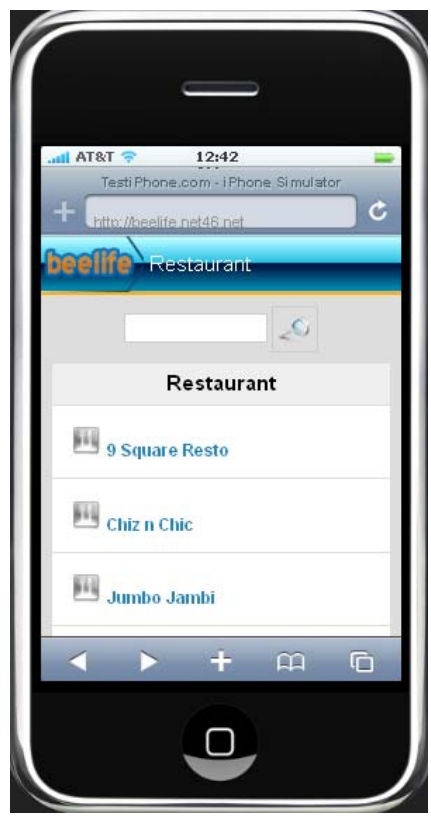

Gambar 4 Tampilan sub menu

Halaman detail menu map (Gambar 5) menampilkan denah lokasi sebuah tempat usaha. Untuk melihat halaman ini, pengguna dapat mengklik menu map yang ada pada halaman detail menu. Halaman ini juga secara default akan ditampilkan saat pertama kali halaman detail menu dibuka. Untuk menampilkan keterangan informasi dan gambar sebuah tempat usaha, pengguna dapat men-tap menu info yang ada pada halaman detail menu (Gambar 6).

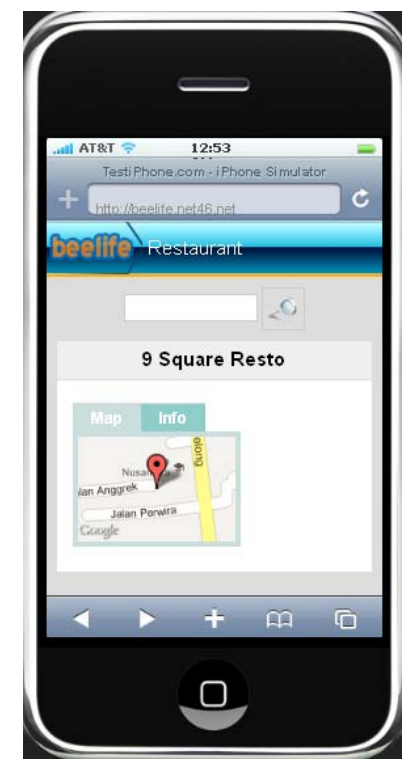

Gambar 5 Tampilan halaman detail menu map

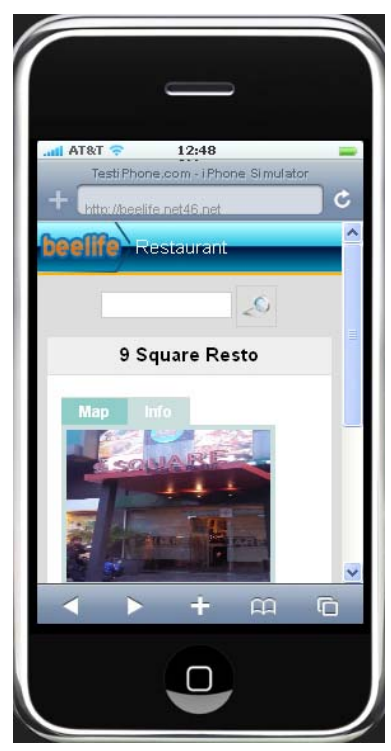

Gambar 6 detail menu info 
Halaman hasil pencarian pengguna ini berupa sub menu. Pengguna dapat mengklik sub menu tersebut, untuk menuju ke halaman detail menu. Search terdapat pada beberapa halaman web. Search digunakan untuk melakukan pencarian sub menu. Dengan cara menuliskan sub menu yang ingin dicari pada kotak input pencarian, kemudian men-tap button search atau menekan enter (Gambar 7). Menu navigasi (Gambar 8) yang berada di header, dapat diklik oleh pengguna untuk menuju ke halaman yang diinginkan. Menu navigasi tersebut juga menunjukkan halaman web yang sedang dibuka oleh pengguna. Halaman about us (Gambar 9) digunakan untuk memperkenalkan web Beelife pada pengguna. Berisi keterangan informasi mengenai web Beelife, animasi logo Beelife, dan video Universitas Bina Nusantara. Pengguna dapat melihat video tersebut, dengan men-tap ikon play.

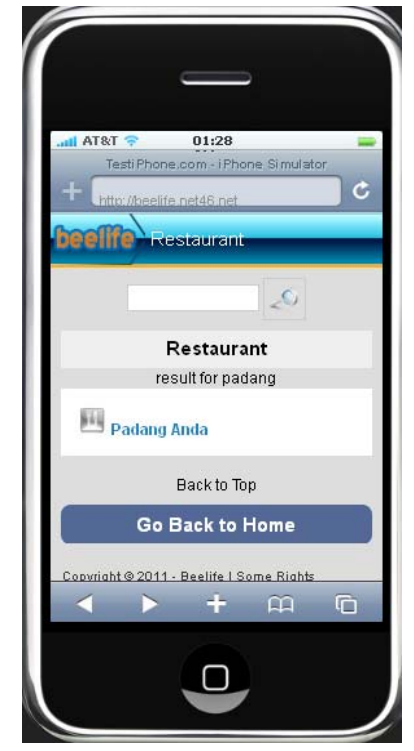

Gambar 7 Tampilan halaman search result

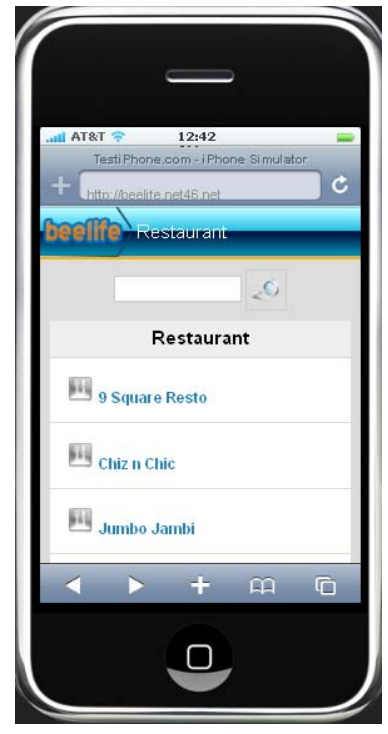

Gambar 8 search dan navigation menu

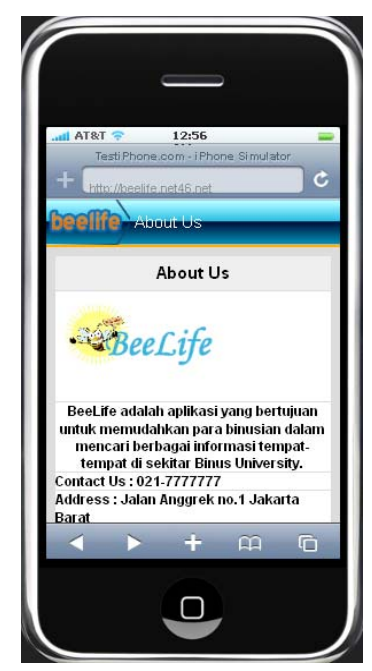

Gambar 9 Tampilan halaman about us untuk pengguna

Setelah selesai, hasil aplikasi tersebut diimplementasikan pada mahasiswa-mahasiswa Binus University, khususnya mahasiswa baru sebagai contoh penerapan aplikasi yang telah di survei pada tahap pengumpulan data sebelumnya. 


\section{PENUTUP}

Dari hasil evaluasi di atas terlihat bahwa penelitian ini telah berhasil merancang suatu aplikasi mobile web untuk digunakan sebagai media informasi dari fasilitas-fasilitas yang ada di sekitar kampus Binus University. Prinsip delapan aturan emas yang diterapkan membuat aplikasi ini sangat mudah digunakan oleh mahasiswa sehingga memudahkan mahasiswa untuk mendapatkan informasi yang diperlukan tentang lokasi dari fasilitas-fasilitas yang berada di sekitar kampus Binus University.

Adapun saran yang dapat diambil dari hasil penelitian untuk pengembangan aplikasi lebih lanjut adalah sebagai berikut: (1) melakukan studi apakah perancangan media informasi dengan prinsip desain antar muka khusus untuk mobile web lebih efektif dibandingkan dengan prinsip delapan aturan emas yang merupakan prinsip desain antar muka secara umum; (2) mengembangkan suatu template yang mudah digunakan dan diakses sehingga dapat digunakan untuk mengembangkan media informasi bagi instansi lain; dan (3) menambah fitur lainnya seperti petunjuk arah dari lokasi pengguna informasi ke tempat usaha yang diinginkan atau area promosi bagi tempat usaha yang berada di sekitar kampus Binus.

\section{DAFTAR PUSTAKA}

Ashraf, M. F., \& Kamal, Y. (2010). Acceptance of mobile marketing among university students. Mustang Journal of Business and Ethics, 1, 9 - 29. Diakses dari http://search.proquest.com/docview/815245286?accountid=31532.

Asif, M., \& Krogstie, J. (2011). Mobile student information system. Campus - Wide Information $\begin{array}{llllll}\text { Systems, } & 28(1), & 5 & - & 15 . & \text { Diakses }\end{array}$ http://search.proquest.com/docview/817166879/fulltext?accountid=31532.

Chen, L. (2009). Design and implementation of an intelligent mobile information system for campus safety management. International Journal of Organizational Innovation (Online), 2(1), 320 340. Diakses dari http://search.proquest.com/docview/194693443?accountid=31532.

Fling, B. (2009). Mobile Design and Development: Practical Concepts and Techniques for Creating Mobile Sites and Web Apps. California: O'Reilly.

Frederick, G. R., \& Lal, R. (2009). Beginning Smartphone Web Development: Building JavaScript, CSS, HTML and Ajax-based Applications for iPhone, Android, Palm Pre, BlackBerry, Windows Mobile and Nokia S60. New York City: Apress.

Ingram, M. (12 April 2010). Mary Meeker: Mobile Internet Will Soon Overtake Fixed Internet. Diakses dari http://gigaom.com/2010/04/12/mary-meeker-mobile-internet-will-soon-overtakefixed-internet/.

The Jakarta Post. (12 Juli 2011). RI Highly Dependent on Mobile Internet. Diakses dari http://www.thejakartapost.com/news/2011/07/12/ri-highly-dependent-mobile-internet.html

Wilson, S., \& McCarthy, G. (2010). The mobile university: From the library to the campus. Reference Services Review, 38(2), $214 \quad-\quad 232 . \quad$ Diakses dari http://search.proquest.com/docview/200539199/fulltext?accountid=31532 